\title{
Pokus o modelování bipolarity praktického a teoretického nazírání
}

\section{Vladimír Spousta}

Mechanismy a technologie dosavadního nazírání a poznávání skutečnosti jsou v intencích postmoderního chápání světa zpochybňovány již od 70 . let 20. století (např. E. Husserlem). Působením ekonomických a politických faktorů se mění paradigmata současné civilizace a naděje jsou vkládány v toleranci a ve vzájemné porozumění. Jestliže se pedagogika jako praktická věda (Wissenschaft der Praxis) přiklání k realitě všedního života (Alltagsorientierung) a současně se odklání od náhledu teoretického, tlačí se do popředí otázka po podstatě vztahu teoretického a praktického poznávání.

Praxi lze chápat jako protipól teorie. Z lidské přirozenosti vyplývá, že ve vývoji lidského poznání světa bylo praktické poznání prvotní a že teoretické poznávání se $\mathrm{z}$ něho začalo odvíjet teprve postupem času paralelně s rozvojem rozumových schopností člověka a jeho myšlení. „... na začátku lidského společenství dominovala praxe, jejímž hlavním cílem bylo přežití,..." (Maňák, 2011, s. 259). U starých Řeků mělo slovo praxis stejný význam jako pragma - čin, jednání, ale též skutečnost. Komenský uznává význam smyslů a praktické zkušenosti při učení; odkazuji i na výrok Johna Lockea z roku 1690 nic není v rozumu, co dřive nebylo ve smyslu. Největší římský rétor Marcus Tullius Cicero nás ještě po více než dvou tisících letech poučí, když ve své Řeči na obranu Rabiria zauvažoval: Usus magister est optimus (Praxe je nejlepší učitelka).

\section{Vztah teoretického a praktického}

Problematika vztahu teorie a praxe patři mezi nejobecnější metodologické otázky vědy. „Filozofické základy vztahu teorie a praxe se vztahují jak k otázkám ontologickým, tak též noetickým. Jde totiž o základní otázku lidského poznání" (Maňák, 2011, s. 260). Teoretické a praktické nazírání představuje dva základní způsoby poznávání světa, které zahrnují v sobě jak duševní, tak i materiální, smyslovou stránku poznávacího procesu. Jestliže teoretické přístupy ke skutečnosti bývají vymezovány jako systém principů, které jsou generovány na základě zobecnění empirických zkušeností, pak praktické př́ístupy mají povahu smyslově předmětnou, cílevědomou a činnostní. Ve vztahu teorie a praxe jsou praktické aktivity jeho hlavní a určující stránkou, protože 
pravdivost a objektivita teoretických závěrů je vždy podmíněna jejich ověřením v praktickém životě. $V$ nejobecnějším významu slova teoretické nazírání představuje vědecký výklad zkušenostní praxe, která má vždy subjektivní charakter; jako záměrné působení člověka na předměty je mění spolu se změnou subjektu tohoto procesu. Praxe se sice permanentně snaží o harmonické „spolužití" s teoretickými koncepcemi, ale nikdy s ní není v souladu. Narůstající nedůvěra mezi oběma póly vztahu teorie a praxe se pak negativně projevuje v tom, že se teorie s praxí vzájemně míjejí.

Reálný vztah teoretické a praktické roviny poznávání má dynamický charakter. Představuje několikastupňový proces, ve kterém empirické poznatky a pozorování přinášejí nová fakta o skutečnosti. $V$ případě, že „nezapadají“ do existujícího teoretického systému (nejsou s ním v souladu), vyvolávají snahu po jeho revizi a restrukturalizaci. Na straně druhé teoretické konstrukty umožňují proniknout hlouběji do reálna a poznat je detailněji. Praktická a teoretická složka tohoto procesu se tak stávají rovnocenným zdrojem poznání, ale současně plní i funkci kritéria při ověřování pravdivosti nových poznatků.

Přestože vztah teoretického a praktického nazírání provází veškeré dění ve všech oblastech lidského usilování, stále se nedaří zřetelně jej popsat, ozřejmit jeho proměny a jasně definovat. Úsilí o jeho objasnění provází celé dějiny lidstva; v jednotlivých etapách jeho vývoje má jen různou podobu, která se formuje v nejrůznějších, více či méně rozdílných koncepcích.

\section{Vztah teorie a praxe $\mathrm{v}$ pedagogice}

Je zásluhou redakce časopisu Pedagogická orientace, že svým třetím, monotematickým číslem z roku 2012 se snaží získat zájem svých čtenářu o tento staronový, věčně aktuální problém. Všechny studie tohoto čísla přinášejí řadu zajímavých a někdy i objevných a teoreticky fundovaných sociohumanitních souvislostí a postřehů. Kromě komentované rekapitulace historických pohledů a vnímání tohoto vztahu od antiky až po novověk se zamýšlejí nad současným stavem řešení těchto otázek $\mathrm{v}$ pedagogice, $\mathrm{v}$ učitelské profesi i v př́ípravě učitelů, ale žádný z nich se detailněji nevěnuje ústřednímu jevu, který je východiskem a základem jejich rozvažování vztahem teorie a praxe $\mathrm{v}$ té nejobecnější rovině, a ani se nepokusil tento vztah postihnout vědecky akceptovatelnými nástroji a vytvořit jeho model.

Např. trojice slovenských autorů Višňovský, Kaščák a Pupala (2012), vybavena filozoficky a teoreticky, pod návěstím Pedagogický dualizmus teoretického 
a praktického... v širokém záběru rozvažuje o vztahu teoretického a praktického vidění a detailně komentuje přínos antické filozofie (Platóna a Aristotela) a sociohumanitních věd. Činí tak ale na pozadí těchto vědních oborů a nikoli na bázi pedagogické, jak bychom vzhledem k titulu příspěvku právem očekávali. Opírajíce se o filozofii jako respektovaný a nejstarší vědní obor, který má za sebou minimálně pětadvacet století svého vývoje, snaží se snad (záměrně, či podvědomě) posílit vědeckost pedagogiky? Jejich text tak téměř z poloviny prezentuje jiné než pedagogické informace, komentáře a úvahy.

Kot’a (2012) ve svém Traktátu... publikovaném v tomtéž čísle Pedagogické orientace podobně rozvažuje o Aristotelově konceptu teorie a praxe a nejednou se tak jeho výklad (s. 341) překrývá s úvahami slovenských autorů (např. na s. 311). Také text tohoto příspěvku obsahuje více než ze dvou třetin úvahy a komentáře založené na antické aristotelovské filozofii. Obdobně i Šobáňová (2012) v úvodní části svého př́íspěvku Co doopravdy jest... téhož monotematického čísla Pedagogické orientace vychází z Platónova a Aristotelova filozofického vidění teorie a praxe (s. 405); čtenáři jsou tak znovu - jen v odlišné dikci - předloženy úvahy už čtené.

Pedagogika má totiž již od doby svého konstituování neustále potřebu obhajovat se jako vědní obor, který by snesl srovnání s jinými, širokou vědeckou komunitou uznávanými vědami. ${ }^{1}$ Tento obtížně řešitelný rozpor vyvěrá ze skutečnosti, že předmětem jejího zkoumání jsou praktické výchovné činnosti, které byly vždy východiskem různých pedagogických teoretických koncepcí, a to i vzdor tomu, že se jen „... obtížně zobecňují v univerzálně platné zákonitosti“ (Maňák, 2011, s. 257). I proto jsou otázky dilematického vztahu mezi teorií a praxí v pedagogice stále živé, diskutované, ale nedořešené. V čem vidím hlavní příčinu oné obtížnosti? Při zkoumání pedagogické reality je neustále a současně př́tomno minimálně pět velmi obsažných množin proměňujících se elementů:

1. Žák jako složitý biofyzický a psychický systém, dispozice a postoje k učení, nadání, proměny jeho zájmů, jeho nálady, rodinné prostředí, vztah $\mathrm{k}$ učivu, ke škole, $\mathrm{k}$ učiteli, k rodičům aj.

2. Kolektiv žáků ve tř́dě: počet žáků, sociální skladba, jejich vztah k předmětu a jeho učiteli, přítomnost a počet narušitelů pracovní atmosféry, celkové klima ve třídě etc.

1 Projevuje se to i v úsilí redakce Pedagogické orientace, která se už několik let snaží o přesun svého periodika z kategorie odborných časopisů do kategorie časopisů vědeckých. 
3. Učební látka: objem poznatků, charakter a náročnost učiva, způsob její prezentace atd.

4. Učitel jako biotická a psychická soustava, jeho genetické dispozice, temperament, povahové vlastnosti, zájmy, hloubka a rozsah vědomostí, profesní aj. dovednosti, hodnotový systém, názorová orientace etc.

5. Společnost: aktuální společenská situace, sociální, politické, ekonomické a kulturní upořádání, úroveň společnosti, virtuální obraz společenského dění v masmédiích atd.

Všechny uvedené faktory se $\mathrm{v}$ reálném výchovném procesu slévají v jednolitý proud, vzájemně na sebe působí, ovlivňují se a každý z nich může vyvolat změnu jiného činitele, který opět může změnit faktory další, ale též zpětně ovlivnit činitele, který onu prvotní změnu způsobil. Tento proces probíhá v dominovém efektu a šírí se lavinovitě. Soubor uvedených pěti systémů, v jejichž prostoru se veškeré výchovné dění odehrává, představuje obrovské množství na sobě více či méně závislých prvků. Jejich citlivost na vzájemné ataky rodící se v průběhu výchovného procesu je nejnázorněji vyjádřitelná teorií motýlích kř́ldel (tzv. motýlím efektem), kdy popud a následná změna v určitém sektoru (fázi) výchovného dění zapř́íčiní změny v sektoru jiném a tak odlehlém, že vzájemnou prríčinnost nejsme ve většině případů s to odhalit.

Tak např. pozdní příchod žáka do třídy jako rušivý zásah do průběhu vyučování se projeví jak v útlumu pozornosti a oslabené soustředěnosti a myšlení žáků (ale i učitele), tak následně i v nekvalitních znalostech nebo ztížené aplikovatelnosti nově nabytých poznatků. Snad jen velký idealista uvěří, že lze $\mathrm{v}$ této obrovské spleti nalézt mezi jednotlivými faktory příčinné souvislosti, které by bylo možno formulovat jako objektivně platné zákonitosti. Naděje, že by pedagogika mohla získat prestiž srovnatelnou s vědami přírodními, se tak jeví jako iluzorní.

J. Průcha, jeden z předních českých pedagogů, postihuje a akcentuje zvláštnost bádání v pedagogice: „... pedagogický výzkum směřuje k využívání poznatků pro praktické účely, tedy $\mathrm{k}$ tvorbě modelů, doporučení, návodů pro praktické aplikace. Tento vztah k praktickým účelům (zvýraznil V. S.) je jednou ze specifičností pedagogického výzkumu" (2006, s. 184). Bohužel toto specifikum neberou na vědomí ani někteří pedagogičtí výzkumníci, ${ }^{2}$ když učí, jak učit na

2 Někdy toto specifikum pedagogiky nezohledňuje dokonce ani vedení pedagogických institucí, když v konkurzech vyhlášených pro pracovníka v oboru pedagogika přijímá uchazeče bez praktických učitelských zkušeností a bez znalosti terénu. 
škole, kterou sami poznali jen z pohledu žáka, ale nikdy z pohledu učitele, tj. aniž by se sami někdy zabývali praktickým vyučováním a zažili atmosféru vyučování a školy „na vlastní kůži“. Zkoumají realitu bez její faktické znalosti. Vybaveni vysokoškolským studiem pedagogiky (nebo jen studiem některého předmětu učitelského zaměření) nahlížejí objekt svého výzkumu pouze optikou své teoretické přípravy a teoretických znalostí, domnívajíce se, že mohou výsledky jejich badatelské práce přinést praktikujícím učitelům objevné závěry, tj. takové, které by je zaujaly, protože poznali, že jim mohou pomoci zkvalitnit a usnadnit práci. Je bohužel jen malá naděje, že budou teoretické rozvahy a konstrukty studovat a pokoušet se aplikovat je do své každodenní výchovné práce. $V$ této souvislosti se nabízí srovnání práce učitele a lékaře. Oběma jde o totéž: o život člověka, o zajištění jeho kvality, lékař však navíc musí být připraven svádět boj i o samo bytí člověka! A dovolilo by si vedení lékařské fakulty přijmout do akademické komunity lékaře, který by neprošel lékařskou klinickou praxí?

Význam hodnoty praktických zkušeností je člověk obvykle schopen plně docenit až ve zralém věku. Dobře vím, o čem ted' píši. Během své šedesátileté učitelské dráhy jsem poznal „slasti a strasti“ kantorského řemesla na všech stupních české školské soustavy: jak výchovnou práci se žáky na 1. a 2. stupni primární školy, tak i didaktické odlišnosti při výuce na několika středních školách různého zaměření, ale též specifika výchovného působení na vysoké škole. Detailní poznání výchovného dění na těchto školách, kde jsem se setkával se zřetelnými odlišnostmi v mentalitě žáků (jejich zájmů, vztahu $\mathrm{k}$ učivu a učiteli), $\mathrm{v}$ povaze a náročnosti učiva, $\mathrm{v}$ preferenci metodických postupů atd., jsem mohl plně zúročit až v pedagogických seminářích při práci se studenty učitelství. A vždy (bez ohledu $\mathrm{k}$ jejich odborné specializaci) se právě tyto ryze praktické poznatky setkávaly u nich s největší odezvou.

\section{Bipolární vztah teoretického a praktického nazírání}

Protože pedagogika je stále v područí filozofie, řeší i dilema vztahu teorie a praxe $\mathrm{z}$ jejích pozic. I když prezentujeme tento vztah jako bipolární a vymezujeme specifika obou způsobů poznávání, zjištuujeme současně, že se jedná o členění, které vzniklo jako teoretický konstrukt. „... mezi teorií a praxí je velmi úzký vztah, ačkoliv vlastně jde o fenomény protikladné" (Maňák, 2011, s. 259). Teoretické poznání není možné a není celistvé bez praktického poznání, ověřování a vzájemné korekce. Teoretické konstrukce, hypotézy atd. na jedné straně a empirická fakta a praktické zkušenosti na straně druhé se 
doplňují a jsou si navzájem oporou. Společně tvoří souběžný proces, jednotu, v níž si oba způsoby poznání neustále vyměňují vedoucí roli, obohacují se a poznání obou proudů se slévá v jeden celek. Teoretické systémy jsou novými poznatky z praxe dotvářeny, zpřesňovány a podle potřeby i měněny. Zpětně pak teorie ovlivňuje způsob nazírání, pojetí a interpretaci nových faktů, které se k ní přiřazují. Jestliže praktickou činností získáváme nové faktické znalosti, pak teoretickou činností je racionálně zpracováváme, tzn. analyzujeme je, zjištujeme souvislosti mezi nimi, případně odhalujeme zákonité spojitosti mezi jednotlivými fakty a začleňujeme je pak do stávajícího teoretického systému, nebo - pokud není konzistentní - vytváříme soustavu novou.

Příspěvek pojednává o bipolárním vztahu praktického a teoretického nazírání a poznání. S pomocí originálních rozdílně koncipovaných modelů analogického a geometrického - s odlišnou průkazností a přesností odkrývá proměny tohoto vztahu. Jeho „jádro“ bylo poprvé veřejně prezentováno před 17 lety na konferenci konané ve dnech 7. a 8. února 2005 ve Šlapanicích u Brna a pod názvem Bipolarita praktického a teoretického nazírání pedagogické reality publikováno $\mathrm{v}$ témže roce ve sborníku Teorie $v$ pedagogické praxi, praxe v pedagogické teorii v učitelském studiu (2005, s. 65-68). Příspěvek zaujal účastníky konference svým zcela novým způsobem uchopení problému a jeho modelováním vědeckým jazykem s využitím symbolických prostředků matematiky a geometrických funkcí.

K rozhodnutí publikovat text s danou problematikou mě vedou čtyři dobré důvody:

1. Pojednané otázky se znovu vynořily jako aktuální a jsou v tisku opět diskutovány (mimo jiné i v časopise Pedagogická orientace, 3/2012).

2. Text uveřejněný v renomovaném odborném časopise skýtá širší publicitu, než když byl v roce 1995 zveřejněn ve sborníku, který neobsáhne tak početnou čtenářskou obec.

3. Způsob, jakým je vztah teoretického a praktického nazírání modelován, je natolik originální, že by neměl ujít pozornosti odborné veřejnosti.

4. Snaha pokusit se iniciovat $\mathrm{v}$ řadách zainteresovaných čtenářů různých odborných orientací diskusi o předložené koncepci a modelování vztahu teoretického a praktického nazírání. 


\section{Modelování bipolarity teoretického a praktického}

Teoretická úroveň poznávání, jejíž metodou je konstruování teoretických modelů, není pouze přirozeným rozvojem možností empirických metod analýzy pedagogických jevů a procesů. Je prostředkem řešení těch složitých problémů, které nelze řešit prostředky a možnostmi empirické roviny (Skalková, 1979, s. 476).

Při konstrukci teoretického modelu vztahu praktického a teoretického poznání vycházím z několika předpokladů (axiomů):

1. Praktické nazírání je základem a výchozí aktivitou lidského (i teoretického) poznání.

2. Praktické poznání provází každou vědomou (tedy i teoretickou) činnost jako její prvotní a základní forma; je její neoddělitelnou součástí.

3. Teoretická činnost a teoretické poznání z praxe vyrůstají jako zobecnění jejích podstatných stránek a k praxi se opět vracejí; př́ípady, kdy existence teoretického modelu skutečnosti je teprve následně potvrzována poznáním praktickým, se vyskytují pouze ojediněle.

4. Ve vztahu k teorii má praktické poznání hlavní a určující funkci, je jejím korektivem.

5. Teorii $v$ nejobecnějším slova smyslu je možno považovat za vědecký výklad praktických zkušeností.

6. Z Zlediska činnostního chápeme praktické poznávání jako druh materiální činnosti člověka, $v$ teoretickém poznání pak můžeme spatřovat druh duševní činnosti.

7. Z aspektu metodologického má teorie charakter praxí ověřené a potvrzené hypotézy.

8. Každá teorie má význam objektivní pravdy, jejíž platnost může být zpochybněna teprve $\mathrm{v}$ př́ípadě, že praxe objeví fakta, která jí odporují.

Všechny uvedené axiomy mají jedno společné: ve všech se setkáváme s principem bipolarity praktického a teoretického nazírání a poznání, s propojením teorie s praxí.

Bipolární vztah praktického a teoretického se pro jeho osvětlení a snazší porozumění pokusím modelovat na základě existence totožnosti některých jeho vlastností. Modelování chápu jako metodu řešení úlohy určitého typu, 
jíž zjednodušujeme obraz skutečnosti (objektu, systému) a konstruujeme ho jako model, s jehož pomocí lze poznat „podpovrchové“ vrstvy originálu a předpovídat jeho chování.

\subsection{Analogický model}

Nejprve prezentujeme kvalitativní (Aristotelovský) analogický model vztahu praktického a teoretického poznání. Protože metoda analogie obvykle není s to přinášet nové poznatky, je opovrhována a metodologie ji nepovažuje za vědeckou metodu. Za předpokladu systémového př́stupu ke skutečnosti se však hodí k aplikaci v př́padě, kdy ze shody dvou nebo více vlastností určitých jevů lze usuzovat na shodu dalších jejich vlastností. Poznatky, k nimž lze dospět, budou ve valné většině pouze pravděpodobné. Proto nelze výsledky získané touto metodou absolutizovat. Tendence $\mathrm{k}$ absolutizaci může plynout $\mathrm{z}$ povrchního porovnání vlastností srovnávaných jevů. $\mathrm{V}$ edukačních vědách se proto používá jen jako pomocná metoda.

Úspěšná může být za těchto podmínek:

1. Srovnávat je možno jen jevy neidentické (nesmí být totožné).

2. Srovnávané jevy musí mít stejné podstatné znaky.

3. Je nutno zřetelně vymezit, $v$ čem se srovnávané jevy liší.

4. Vztahy mezi vlastnostmi jevu musíme studovat se zřetelem $\mathrm{k}$ těm vlastnostem, o nichž usuzujeme $\mathrm{z}$ analogie.

Na základě analogie (podob, shod) s originálem vytváříme odpovídající model s jeho strukturou a vlastnostmi, který nám umožňuje hlubší vhled a následně i nové informace o originálu. $S$ jeho pomocí můžeme zjištovat společné znaky tohoto vztahu s postupy (včetně terminologie), které užívá kameraman při vytváření obrazu skutečnosti. Srovnáním podobností mezi oběma množinami jevů se pokusíme vyvodit některé závěry. 


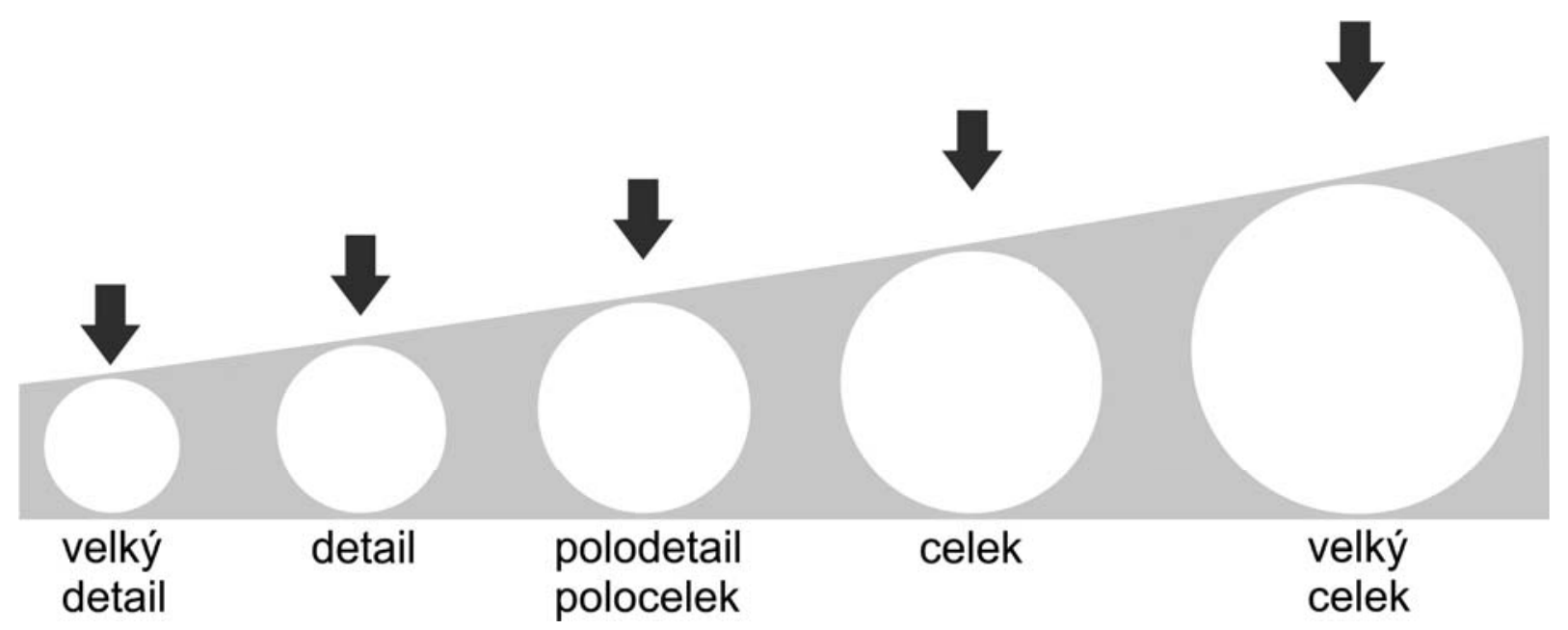

Obrázek 1. Schéma analogického modelu

Legenda (obr. 1): Pakliže při velkém detailu pozorovatel nahlíží objekt z nejmenší možné vzdálenosti, pak při velkém celku je od objektu vzdálen nejvíce, a proto je $s$ to spatřit i jiné jevy $v$ jeho okolí a pozorovat a hodnotit vztahy mezi nimi.

Ocitáme-li se při praktické činnosti v těsném kontaktu s objektem svého zájmu (jsme mu nejbliže), máme možnost zkoumanou realitu poznat z bezprostřední blízkosti, ve všech detailech včetně její nejjemnější struktury. Stejně tak nahlíží na pozorovaný objekt kamera záběrem zvaným velký detail, kdy se (např.) dívá do očí a rozeznává jejich barevné polotóny. Odstoupíli pozorovatel od objektu, podrobnosti už nevidí, ale upoutá ho jeho okolí, podobně jako kamera snímající v polodetailu celou postavu člověka. Tak jak se od sledovaného objektu postupně odpoutáváme a vzdalujeme, přestáváme vidět stále méně detailů a upoutá nás okolí a prostředí, ve kterém se objekt vyskytuje. Kameraman volí pro svůj záběr celek nebo polocelek, aby mohl v záběru zachytit např. aviatika nastupujícího do horkovzdušného balonu. Ve fázi pozorování, kdy se zájem pozorovatele upíná k jevům, které objekt obklopují, kamera využívá objektivu s nejkratší ohniskovou vzdáleností, kterým lze snímat obraz v nejširším úhlu záběru (velký celek). Rozhled ze vznášejícího se balonu pak umožňuje divákovi spatřit (napřs) silniční, železniční aj. komunikační sít', rozložení městských čtvrtí a morfologii krajiny v okolí města, tedy vše, co lze spatřit jen z velkého nadhledu při odpoutání se od reality př́i zemi. 
Francouzský filozof a matematik René Descartes postihuje ve své Rozpravě o metodě, jak správně vést svi̊j rozum a hledat pravdu ve vědách z roku 1637 tuto cestu od jednoduchého a smyslově poznatelného k nejsložitějšímu rozumovému poznánív jednom ze svých čtyř metodických pravidel vědeckého poznání: „...vyvozovat $\mathrm{v}$ náležitém pořadí své myšlenky, počínaje předměty nejjednoduššími a nejsnáze poznatelnými, ${ }^{3}$ stoupaje povlovně jakoby ze stupně na stupeň až k znalosti nejsložitější, a předpokládaje dokonce i řád mezi těmi, jež přirozeně po sobě nenásledují."

Při teoretickém nazírání se tedy musíme od pozorované reality vzdálit, abychom získali potřebný odstup. Čím větší odstup získáme, tím více se zvětšuje zorné pole vidění a současně se rozšiřuje prostor, v němž můžeme sledovaný jev pozorovat. Tím získáváme i větší přehled a globální nadhled (kameraman volil velký celek). Úměrně tomu se zvětšují i naše možnosti odkrývat v dané oblasti zkoumání vzájemné souvislosti jevů, které nám dříve unikaly, včetně jejich hierarchického uspořádání.

Současně se zvětšujícím se odstupem od objektu zkoumání ztrácíme však možnost hlubšího vhledu, a tím i možnost postihnout jednotliviny a zkoumanou skutečnost analyzovat detailně. $V$ př́ípadě opačném - při praktickém nazírání, kdy se zmenšujícím odstupem od objektu zkoumání pozbývá možnost globálního vidění, unikají nám souvislosti, ztrácíme přehled a vystavujeme se riziku, že zahlceni podrobnostmi budeme se utápět $v$ jednotlivinách („pro stromy nebudeme vidět les“).

\subsection{Geometrický model}

V geometrickém modelu se pokoušíme bipolární vztah teorie a praxe modelovat matematicky. Jeho dvojpólovost demonstrujeme rozdílnou vzdáleností „stanoviště“ pozorovatele od objektu pozorování. Činíme tak s vědomím, že jde pouze o jeden z možných způsobů jeho formalizace. Vycházíme přitom ze základního předpokladu, který má v procesu nazírání charakter proměnné: zorné pole nazírání se plynule mění v závislosti na odstupu pozorovatele od zkoumané reality. Schematické znázornění tohoto vztahu lze chápat jako průmět (stereogram) průniku koule, symbolizující objekt pozorování, a rotačního kužele, $v$ jehož prostoru nachází pozorovatel své stanoviště. Uvedený vztah teoretického a praktického nazírání reality formulujeme mate-

3 Nejsnáze poznatelnými předměty má Descartes (podle Jana Patočky) na mysli racionální principy poznání, na nichž je založena veškerá skutečná věda. 
maticky jako tg $\alpha=d / r$, kde úhel $\alpha$ je svírán přeponou $A_{1} S$ a odvěsnou $S T=r$ pravoúhlého trojúhelníka $A_{1} S T$; $d$ je odvěsna $A_{1} T, A_{1}$ a $A_{2}$ jsou stanoviště pozorovatele.

$$
\operatorname{Tg} \alpha=\frac{d}{r}
$$

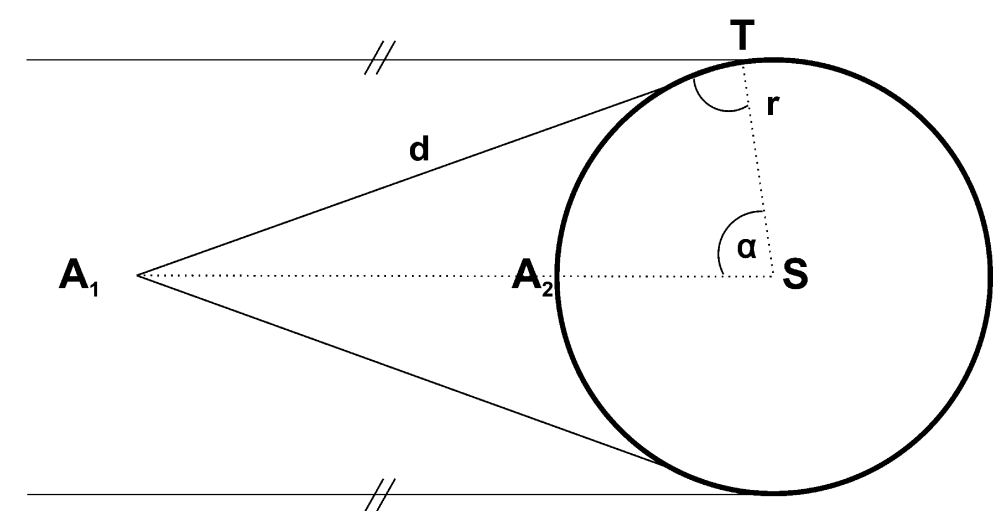

Obrázek 2. Vztah teoretického a praktického nazírání.

Schéma (obr. 2) interpretujeme takto: Bude-li se stanoviště pozorovatele $A_{1}$ posouvat směrem $\mathrm{k}$ nekonečnu $\left(A_{1} \rightarrow \infty\right)$, pak délka odvěsny $d \mathrm{v}$ trojúhelníku $A_{1} S T$ se bude zvětšovat a velikost úhlu $\alpha$ se bude blížit $90^{\circ}\left(\alpha \rightarrow 90^{\circ}\right)$. Pozorovaný objekt bude možno nahlížet v širokém zorném úhlu a registrovat souvislosti a vztahy s jinými objekty v jeho okolí, zjištovat i jejich vzájemné vztahy, jejich povahu a hierarchické uspořádání, rozvažovat o příčinách vzniku a následcích každého z nově objevených vztahů a vyvozovat nové zákonitosti a konstituovat nové teorie.

V opačném případě, kdy se stanoviště $A_{1}$ bude blížit bodu $A_{2}\left(A_{1} \rightarrow A_{2}\right)$ a délka odvěsny $d$ se bude zkracovat, pak velikost úhlu $\alpha$ se bude blížit $0^{\circ}\left(\alpha \rightarrow 0^{\circ}\right)$ a pozorovatel může nahlížet do nejjemnějších detailů objektu a „vidět až na dno“. Teoreticky je možno uvažovat i obě krajní pozice, kdy stanoviště pozo-

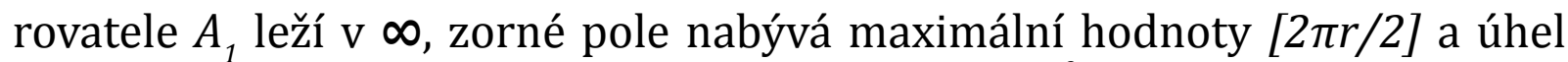
$\alpha=90^{\circ}$, nebo kdy $A$ splyne s $A\left(A_{1} \equiv A_{2}\right)$, úhel $\alpha=0^{\circ}$ a zorné pole má nulový rozsah. $\mathrm{V}$ obou těchto krajních préípadech (při mezních hodnotách) pozbývá však pozorovatel reálnou možnost objekt pozorovat. Pro naši rozvahu je tato skutečnost matematicky modelována stanovením mezních hodnot úhlu $\alpha$ : $\operatorname{tg} \alpha=d / r$ je definováno pro úhel $0^{\circ} \leq \alpha \leq 90^{\circ}$. Z uvedeného vztahu též vyplývá, že pro úhel $\alpha=0^{\circ}$, ale též pro úhel $\alpha=90^{\circ}$, není poměr $d / r$ definován. Jazykem 
exaktní vědy je tak vyjádřena situace, již lze (zvláště v případě, kdy stanoviště $A_{1}$ splývá se stanovištěm $A_{2}$ ) experimentálně ověřit, poznat její nereálnost a přesvědčit se o její praktické nepoužitelnosti, vyplývající z omezených (anatomicky a fyziologicky limitovaných) možností našeho smyslového vnímání a nazírání. ${ }^{4}$

Na závěr vyčleňujeme vybrané přiznačné rysy praktického a teoretického nazírání tak, jak se vyjevují v průběhu předchozí úvahy, a řadíme je do bipolárních dvojic: k symptomu praktického nazírání je dichotomicky řazen symptom nazírání teoretického. Jestliže pro praktické nazírání je příznačný bezprostřední, těsný kontakt s realitou, pak pro teoretické poznání je typický odstup od sledované skutečnosti a nazírání z nadhledu. Vzdor tomu, že podstupujeme riziko „černobílého vidění“ a vystavujeme se nebezpečí př́lišného zploštění (a tím i možného zkreslení problému), klademe proti sobě např. tyto bipolární dvojice:

$$
\begin{gathered}
\text { materia - idea } \\
\text { fysis - psyche } \\
\text { tělesno - duševno } \\
\text { živý - mrtvý } \\
\text { organický - schematický } \\
\text { infinitivní - finitivní } \\
\text { empirie - racionalita } \\
\text { blízkost - vzdálenost } \\
\text { úzké zorné pole - široké zorné pole } \\
\text { jednotliviny - celek } \\
\text { vnějškovost/povrchnost - vnitřnost/struktura } \\
\text { vhled - přehled, nadhled } \\
\text { detailní - globální } \\
\text { analýza - syntéza } \\
\text { indukce - dedukce } \\
\text { konkrétní - abstraktní } \\
\text { konkretizace - formalizace } \\
\text { smyslové - myšlené }
\end{gathered}
$$

4 V souvislosti s oběma prezentovanými modely si dovolím malé osobní ohlédnutí. I mezi vysokoškolskými studenty se obvykle najdou tací, kteří na střední škole neměli matematiku v oblibě, a proto jim geometrický model vztahu teorie a praxe nebyl příliš srozumitelný. Nechápavý výraz jejich tváře se však rozjasnil, jakmile jsem jim prezentoval i model analogický. 


$$
\begin{gathered}
\text { realita - imaginace/pojem } \\
\text { obsah - forma } \\
\text { jedinečné - obecné } \\
\text { nahodilost - zákonitost } \\
\text { chaos - řád } \\
\text { projev - př́čina projevu } \\
\text { subjektivita - objektivita } \\
\text { činnosti - myšlení/znalosti } \\
\text { praktické poznání - teoretické poznání }
\end{gathered}
$$

Jestliže na základě smyslového poznání dospějeme k myšlenkové reprodukci přírodníči umělecké reality a k poznání konkrétnímu, vyčleněním podstatných vlastností daného jevu a odhalením obecných, nutných a relativně opakovatelných vztahů mezi těmito vlastnostmi vytváříme jeho abstraktní „obraz" a dospíváme tak k poznání abstraktnímu.

\section{Závěrem}

Vývoj poznání chápemeve shoděs názory rakouského filozofa Karla R.Poppera (1992, s. 492) jako neustálý přirozený výběr mezi stávajícími (obvykle si konkurujícími) teoriemi, jejichž platnost je nutno znovu a znovu verifikovat konfrontací s výsledky praktického poznání. S jistou mírou tolerance můžeme tedy konstatovat, že $\mathrm{k}$ plnohodnotnému poznání reality lze dospět jen v procesu neustálé oscilace mezi oběma póly poznání a permanentním, nikdy nekončícím ověřováním jejich výsledků. Praxe nám vždy bude východiskem, ale i korektorem teorie. Jak už to při vědeckém myšlení bývá téměř pravidlem, při každém učiněném kroku za poznáním se otevírají nové obzory a objevují se nové otázky; i při promýšlení a konstruování obou modelů se vynořila řada nových navazujících otázek:

- (V prvé řadě) - Jak by bylo možno matematický model teoretického a praktického nazírání světa využít při řešení konkrétních praktických problémů?

- Jakou hodnotu by měl mít tg $\alpha$ pro vyjádření optimálního poměru teoretického a praktického $\mathrm{v}$ pedagogických (přírodních, sociálních aj.) vědách?

- Za jakých podmínek by bylo možno jeho hodnotu stanovit? 
Protože text přináší nový pohled na vztah teorie a praxe, má proto i sílu vyprovokovat diskusi. Neuzavírám ho proto školácky formulovanými otázkami, ale spíše spoléhám na čtenáře. Jsem totiž přesvědčen, že kultivovaný čtenář bude s to sám sobě položit otázky (a navíc ve vztahu ke své odbornosti a specializaci), že bude hledat odpověd' a ochotně se o svůj názor a své vidění pojednávané problematiky se čtenáři časopisu podělí.

\section{Literatura}

Descartes, R. (1947). Rozprava o metodě, jak správně vést svůj rozum a hledat pravdu ve vědách. Praha: J. Leichter. (český překlad V. Szathmáryová-Vlčková)

Husserl, R. (1972). Krize evropských věd a transcendentální fenomenologie. Praha: Svoboda.

Kot’a, J. (2012). Traktát o vybraných problémech teorie a praxe v oblasti pedagogických věd. Pedagogická orientace, 22(3), 336-352.

Maňák, J. (2011). K problému teorie a praxe v pedagogice. Pedagogická orientace, 21(3), 257-271.

Popper, K. R. (1992). Die offene Gesellschaft und ihre Feinde. Sv. II. Tübingen: J. C. B. Mohr.

Průcha, J. (2006). Přehled pedagogiky. Praha: Portál.

Skalková, J. (1979). Jednota teorie a empirie. Pedagogika, 29(5), 467-478.

Spousta, V. (1995). Bipolarita praktického a teoretického nazírání pedagogické reality. In V. Jůva (Ed.), Teorie v pedagogické praxi, praxe v pedagogické teorii v učitelském studiu (s. 65-68). Brno: Paido.

Šobáňová, P. (2012). „Co doopravdy jest“ aneb vztah teorie a praxe ve výtvarné výchově. Pedagogická orientace, 22(3), 404-427.

Višňovský, E., Kaščák, O., \& Pupala, B. (2012). Pedagogický dualizmus teoretického a praktického: historické pozadie a súčasné ilúzie. Pedagogická orientace, 22(3), 305-335.

\section{Pedagogika.sk 1/2013}

První číslo čtvrtého ročníku obsahuje studie od autorů ze tří zemí. S. Gallová a E. Katreniaková ve studii Čitatel'ská gramotnost' žiakov štvrtého ročníka základných škôl: súvislosti s vekovými rozdielmi žiakov v rámci jedného ročníka dokázaly, že věkové rozdíly mezi žáky jednoho ročníku mohou představovat až 12 měsíců, což významně ovlivňuje výkony žáků v testech gramotnosti. J. Mareš v přehledové studii Užití humoru v elektronickém učení shrnuje dosavadní poznatky o vlivu humoru na studenty, na vztahy mezi studenty, na vnímané role učitele, na vztah mezi učitelem a studenty při on-line učení a na klima „virtuální tř́ídy“. B. Śliwerski ve studii Pedagogické smery modernizmu představuje diferenciaci a klasifikaci trendů v pedagogickém myšlení v období moderny. Číslo časopisu obsahuje také recenze čtyř publikací a zprávy.

http://www.casopispedagogika.sk 